\title{
Article
}

\section{Social meanings of linguistic variation in BISINDO (Indonesian Sign Language)}

Palfreyman, Nick

Available at http://clok.uclan.ac.uk/33641/

Palfreyman, Nick ORCID: 0000-0002-9095-4937 (2020) Social meanings of linguistic variation in BISINDO (Indonesian Sign Language). Asia-Pacific Language Variation, 6 (1). pp. 89-118. ISSN 2215-1354

It is advisable to refer to the publisher's version if you intend to cite from the work. http://dx.doi.org/10.1075/aplv.00008.pal

For more information about UCLan's research in this area go to

http://www.uclan.ac.uk/researchgroups/ and search for <name of research Group>.

For information about Research generally at UCLan please go to http://www.uclan.ac.uk/research/

All outputs in CLoK are protected by Intellectual Property Rights law, including Copyright law. Copyright, IPR and Moral Rights for the works on this site are retained by the individual authors and/or other copyright owners. Terms and conditions for use of this material are defined in the policies page.

\section{CLoK}

Central Lancashire online Knowledge www.clok.uclan.ac.uk

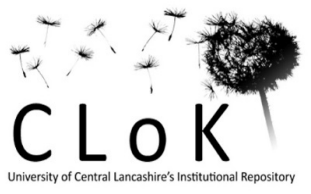




\title{
Social meanings of linguistic variation in BISINDO (Indonesian Sign Language)
}

Nick Palfreyman, University of Central Lancashire

\begin{abstract}
In contrast to sociolinguistic research on spoken languages, little attention has been paid to how signers employ variation as a resource to fashion social meaning. This study focuses on an extremely understudied social practice, that of sign language usage in Indonesia, and asks where one might look to find socially meaningful variables. Using spontaneous data from a corpus of BISINDO (Indonesian Sign Language), it blends methodologies from Labovian variationism and analytic practices from the 'third wave' with a discursive approach to investigate how four variable linguistic features are used to express social identities. These features occur at different levels of linguistic organisation, from the phonological to the lexical and the morphosyntactic, and point to identities along regional and ethnic lines, as well as hearing status. In applying third wave practices to sign languages, constructed action and mouthings in particular emerge as potent resources for signers to make social meaning.
\end{abstract}

Key words: Indonesian Sign Language, variation, identity, styles, third wave

\section{Introduction}

Many of the recent sociolinguistic studies on sign languages have explored correlations between linguistic variables and macro-social factors such as sex, ethnicity, region and age (e.g., Lucas, Bayley, \& Valli, 2001; McCaskill, Lucas, Bayley, \& Hill, 2011; Sagara $\&$ Palfreyman, this issue; Schembri et al., 2009). The aim of these quantitative studies is to investigate the variable articulation of phonological parameters, such as the location of a sign, or the variable presence of a feature, such as first-person pronouns. The findings show that - as with spoken languages - sign language variation is not random, but patterns according to certain linguistic and macro-social variables (Lucas \& Bayley, 2016). This research contributes greatly to our understanding of the variation found across several sign languages but remains very much in the tradition of Variationist Sociolinguistics.

In this study, I look at Indonesian Sign Language (BISINDO) instead from a social constructionist perspective, exploring how BISINDO signers use variation to construct social meanings and identities. This is something of a novel endeavour for sign language sociolinguistics, and it is not clear at the outset where in the language one should look to find socially sensitive variables. Modality differences - differences in the 
way that signed and spoken languages are produced and perceived - are known to have consequences for many domains of (socio)linguistics (see Zeshan \& Palfreyman, in press, for an overview) and one cannot assume a priori that the same kinds of variables will be relevant in the making of social meaning for both speakers and signers.

With these points in mind, I take an inductive approach, using a corpus of spontaneous BISINDO data. These data have been studied closely for instances where social identities emerge, and interpretation is assisted by linguistic ethnography (see Section 3). Two questions are central to this enquiry: which forms or features are used to construct or express identities, and what kind of social meanings can these create? To answer these questions, I look at four discrete linguistic variables, and how signers use them for social identification. The four variables are considered according to the level of linguistic organisation at which they occur, resulting in a series of examples where signers appropriate variation as a means of forging social identities.

The first of these variables occurs at the phonological level, where the production of a variant triggers an expression of regional identity (Section 4). This is particularly important because, while there are many examples of phonological variables as markers or stereotypes for regional identity in spoken languages, this has not previously been attested in the literature on sign languages (see Section 2).

The second and third variables both occur during periods of talk where signers construct the actions, thoughts, feelings and opinions of others using constructed action (CA). ${ }^{1}$ I suggest that the use of CA by signers enables the creation of social identities in very different ways, with signers switching between variants as they construct the identities of the people they are enacting (Section 5). In the first instance, a signer uses $\mathrm{CA}$ in a particular context to mimic and evaluate an idiosyncratic lexical variant used by another signer. In the second instance, a signer switches between grammatical variants for negation. Quantitative and qualitative evidence suggests that she does this to create distinct deaf and hearing characterisations of the participants in the dialogue she enacts.

The final variable is non-manual, a term used in sign linguistics to include facial expressions such as eye gaze, movements of the eyebrows, lips and tongue. Lip movements include 'mouthings', where a signer imitates the patterns visible on the lips of hearing speakers (Boyes Braem \& Sutton-Spence, 2001). The variable in question occurs when signers switch between mouthings from different spoken languages to index a distinct Javanese identity (Section 6), a practice that effectively cuts across the deaf-hearing divide.

This is one of several instances of 'othering' practices that signers use to assist with forging social identities. 'Deaf identity' is much discussed in the literature (Bienvenu, 1991; Ladd, 2003; McIlroy \& Storbeck, 2011; Padden \& Humphries, 2006; Van Cleve $\&$ Crouch, 1997), and one of the (deaf) signers in the data uses variation to identify

\footnotetext{
${ }^{1}$ This and related phenomena are referred to by a host of different terms in the literature, including 'Constructed Action', 'role shift', and 'enactment' (e.g., see Tannen, 1989, for spoken languages and Ferrara \& Johnston, 2014; Hodge \& Ferrara, 2013; Hodge, Ferrara \& Anible, 2019; and Metzger, 1995, for sign languages).
} 
over-against a hearing person. Equally, while acknowledging that signers share a language modality, and may also share a strong cultural affinity based on deafness, researchers have recently started to acknowledge 'substantial differences between deaf people from different backgrounds... [including] nationality, ethnicity, class, mobility, educational levels, and of course, language...' (Kusters \& Friedner, 2015, p. x). The example presented in section 6 points to how variation enables the expression of ethnic identity, as some Javanese deaf people align themselves with Javanese hearing people against other deaf people who are not Javanese. Indeed, given the multifarious uses of spoken language variation for 'othering' (Antaki \& Widdicombe, 1998; Bristowe, Oostendorp, \& Anthonissen, 2014; Bucholtz \& Hall, 2004; Farrell, 2008; Hamid \& Jahan, 2015; Llamas, 2006; Wortham, 2006), it might come as no surprise that signers do this too.

The paper concludes with a discussion of how the use of these linguistic features can best be categorised, and how sociolinguists might address some of the challenges that arise when seeking to apply a social constructionist framework to sign language data (Section 7). Before that, I provide a synthesis of relevant literature on variation in spoken and signed languages (Section 2) and outline the research context and method (Section 3).

\section{Variation and social meaning in spoken and signed languages}

In the field of language variation and change, Penelope Eckert - noted for her 'radical rethinking of sociolinguistic variation as a resource for situated meaning-making' (Coupland, 2016, p. 13) - finds three successive and complementary waves of analytic practice. The first, Labovian wave examines groupings such as class, gender, sex and ethnicity, and is typified by an essentialist approach to identity, viewing the social as part of a fixed structure shown only through relations between linguistic variation and macro-sociological categories (Eckert, 2008, p. 454). The second wave uses ethnographic methods to investigate 'local categories and configurations' (Eckert, 2012, p. 87), but regards variation as marking those categories.

Practitioners of the third wave build upon theories of indexicality (Silverstein, 2003) and focus on the ways in which language users construct identities, styles and personae (Bucholtz, 1996; Cameron, 2000; Eckert \& Rickford, 2001; Schilling-Estes, 2004; Zhang, 2008). In looking at how variation is situated and used on a regular basis, these practitioners have uncovered new insights on human competence (Eckert, 2008). For the most part, however, these practices are still to be applied to sign languages; major studies of sign language sociolinguistics 'have not yet examined any particular region's deaf community to the same depth that is common in ethnographic studies of spoken language variation and change' (Schembri \& Johnston, 2013, p. 519).

The extent to which the assumptions that are associated with the three waves apply to sign language variation is also less well-explored. For example, sound changes 
typically occur across the phonological system, and may not affect all speakers equally, but are mediated by social factors such as region, gender and class (Labov, 1994, 2001). At the phonological level, signs comprise parameters - the handshape, orientation, location and movement of the sign - and Lucas et al. (2001) show how parameter variation in ASL also occurs across the phonological system. For example, signs that have a ' 1 ' handshape for their citation forms, with the index finger extended, may also be produced with an extended index finger and thumb. Likewise, signs with citation forms articulated at the temple may vary with respect to location and are not uncommonly located lower in the sign space. Furthermore, these are mediated, as with many phonological variables in spoken languages, by macro-social factors - including region (Lucas et al., 2001).

For spoken languages, however, it is also well-attested that certain phonological variants become overtly associated with particular regions, as markers and stereotypes, and that prestige judgements are often made in accordance with the realisation of phonological variables (McMahon, 1994; Edwards, 2011). Matched guise tests reveal shared attitudes to the variable expression of key phonological variables; that is, speakers attribute social characteristics such as region to people who produce variables in a certain way (Drager, 2013). Such insights have not yet been found to apply to region in sign languages at the phonological level. For their handshape study, Lucas et al. (2001, p. 101) find that signers in California, Kansas/Missouri, Louisiana and Massachusetts favour the ' 1 handshape', while signers in Maryland, Virginia and Washington disfavour this handshape. While this variable is an indicator for region, it does not appear to be a regional marker at the phonological level, let alone a stereotype, because it does not operate above the level of awareness - a tell-tale sign of markers and stereotypes (McMahon, 1994). This sets the scene for section 4, where I discuss an example of phonological variation in BISINDO that is used for regional demarcation.

Returning to the third wave, Eckert $(2008$, p. 87$)$ notes that the meanings of variables are underspecified, and that more specific meanings emerge in the context of styles. Third wave sociolinguistic research has had much to say about styles, including work produced by the Half Moon Bay Style Collective (Campbell-Kibler, Eckert, Mendoza-Denton, \& Moore, 2006). One facet of style is personae, 'particular social types that are quite explicitly located in the social order' (Eckert, 2019), and examples from Beijing identified by Zhang (2008) include 'the alley saunterer' and the 'smooth operator'. I reflect on evidence of personae in sign languages in Section 5.

Another way in which sociolinguists have sought to uncover social identification in interaction is by studying code-switching: the alternation between linguistic varieties in the same conversation (Myers-Scotton, 1993; Gardner-Chloros, 2009). Such codeswitching is attested in several studies of speech communities in Java: Errington (1998) and Goebel (2007) both use macro- and micro-level analyses to classify and interpret alternation between Javanese and Indonesian, and draw attention to how subtle changes in alternation occur in situated talk. Goebel (2007) in particular highlights the link between code-switching and enregisterment - the association of linguistic forms with 
particular social structures and characteristics (Agha, 2003; Silverstein, 2003) - and this becomes pertinent especially in Section 6, where I explore a parallel example of alternation that occurs in the mouthings of BISINDO users.

\section{Research context and method}

Indonesia is spread across the world's largest archipelago, with around 265 million people living on several thousand islands (BPS, 2019). Its spoken language situation is complex, with many varieties of Malay used alongside hundreds of regional and local languages (Sneddon, 2003). The national language, referred to here as Indonesian, is a standardised form of Malay and has played a major role in creating national identity (Bertrand, 2003). However, Indonesian is a second language for most hearing people, and the language of the home is likely to be one of several hundred distinct languages, such as Javanese, Batak or Buginese (Robson, 2004).

Data concerning the number of deaf Indonesians are unreliable, and an accurate figure for the number of sign language users is currently unobtainable. Not all deaf people in Indonesia use sign language, and some prefer - or have been forced - to communicate orally (Palfreyman, 2015); many other deaf people are thought to be linguistically isolated, living in rural areas where there are no opportunities to meet other deaf signers. Despite this, varieties of BISINDO are used in urban centres by tens if not hundreds of thousands of deaf people across the Indonesian archipelago (Palfreyman, 2019). Research on BISINDO began in earnest relatively recently, with work on varieties in Java (Isma, 2012; Isma, Bharoto, \& Novitasari, 2018; Wijaya, 2017) and on lexical and grammatical variation in Solo (Central Java) and Makassar (South Sulawesi) (Palfreyman 2013, 2016, 2019).

The analysis in this study is based on spontaneous, conversational data from 37 BISINDO users in Solo and Makassar, collected in 2010-11. A total of three hours of conversational video data were selected for analysis ( 90 minutes from each city), broadly balanced for age, sex and city (see Palfreyman, 2019, p. 92). These data are now part of the larger BISINDO Corpus featuring 131 signers in six cities: data from the other four cities - Ambon, Pontianak (West Kalimantan), Padang (West Sumatra) and Singaraja (Bali) - were collected in 2016-17. ${ }^{2}$ All data were transcribed using ELAN (Sloetjes, 2014) as part of a co-creative endeavour with local research assistants who are members of the sign community and lifelong BISINDO users. Given the involvement of these local deaf assistants in data transcription and annotation, glosses in the Corpus are in Indonesian, the written language in which they are most literate. The Corpus is currently being archived, with the aim of making videos and transcriptions available to other researchers.

\footnotetext{
${ }^{2}$ These six sites provide a wide geographic spread and go some way to reflecting the diverse religious and ethnic make-up of Indonesia. The ability of the local deaf community to work with the researcher was also an important consideration in choosing fieldsites.
} 
Ethical approval for the Solo and Makassar data collection was obtained from the Business, Arts, Humanities and Social Sciences ethics committee at the University of Central Lancashire in September 2010, and permission for research was granted by the Indonesian Ministry for Research and Technology (0128/SIP/FRP/SM/VII/2011). Data were collected as part of a long-term collaboration with the Indonesian deaf community (see Palfreyman, 2019, for details). Participants were initially identified, approached and recruited with assistance from local deaf research assistants, using convenience sampling. Consent was obtained from all participants and was as 'informed' as possible; this and other ethical considerations are discussed at length in Palfreyman (in press).

This study uses linguistic ethnography, an interpretative approach that examines the 'local and immediate actions of actors from their point of view and considers how these interactions are embedded in wider social contexts and structures' (Copland \& Creese, 2015, p.13). Sociolinguists have employed ethnographic approaches for discursive analysis to great effect (for example Eckert, 2000; Schilling-Estes, 2004), and such approaches are well-suited to challenging essentialist views of the language practices of deaf people (Hou \& Kusters, 2019, p. 341).

While conducting sociolinguistic analysis on the data in the Labovian paradigm (Palfreyman, 2019), I noted moments in the text where variants appear to be used at the micro-level to construct social identity. To shed light on these incidents, I then conducted interviews with research assistants to explore the attitudes and ideologies of community members, and I drew on observations from my long-standing contact with the Indonesian deaf community. As a deaf volunteer (2007-9) and then as a researcher (since 2010), BISINDO was both the medium of communication and the focus of much of my work. Through regular contact, I acquired fluency in varieties of BISINDO used in Yogyakarta, Solo and Jakarta from members of various deaf organisations, and together we learnt about the importance of sign language as a means of developing the capacity and capability of the Indonesian deaf community. Ongoing contact has afforded many opportunities to observe the use of sign language by deaf Indonesians, to learn about the wider sociolinguistic context, and to reflect critically together on the functions that variation can express.

\section{Phonological variation and social meaning}

In Section 2, it was mentioned that studies examining phonological variation in sign languages have not provided evidence of phonological variants that index regional identity. Indeed, in comparison to the proliferation of research on the indexical properties of phonological variables in spoken languages (Tagliamonte, 2012), discussion of phonological variants as markers of region in sign languages has been striking in its absence. I turn to this in my discussion of Example I, where phonological variation is given a particular social meaning by two signers from Makassar. 


\section{Example I: Phonological variation in Makassar}

The conversational data in the BISINDO Corpus take the form of dyads, triads and tetrads, and includes a tetrad of female signers aged between 17 and 43 . Three of these signers are from Makassar (Signers B, C and D), while one (Signer A) had recently moved to Makassar from Java. Variation in an utterance from Signer A prompts a conversation between two of the others (C and D) which appears to be motivated at least in part by considerations of regional identity.

The trigger for this discussion is the use, by Signer A, of a sign meaning 'sibling' that is different to the one with which Signer $\mathrm{C}$ is familiar. The two signs are glossed here as SAUDARA:1a and SAUDARA:1b (shown in Figure 1) and are regarded as phonological variants. Phonological variants are taken to derive either from a common original source, or from each other, through processes linked to morphophonological variation and change (Palfreyman, 2016, p. 276). In accordance with the way these terms are used in the literature, phonological variants tend to vary in one parameter, and have several other parameters in common.

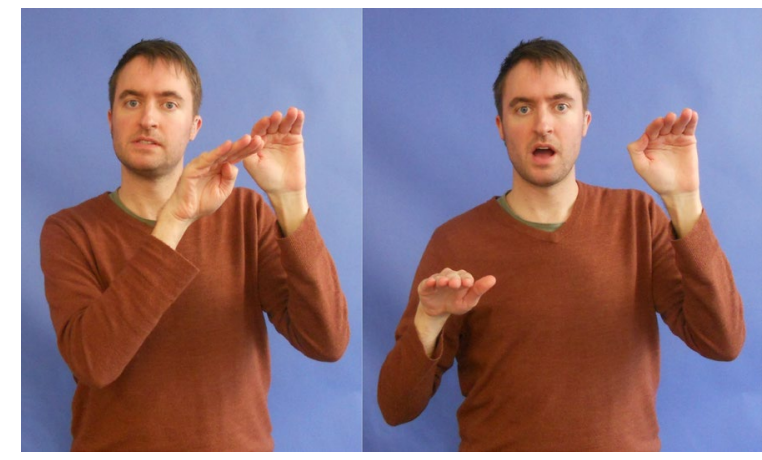

SAUDARA:1a

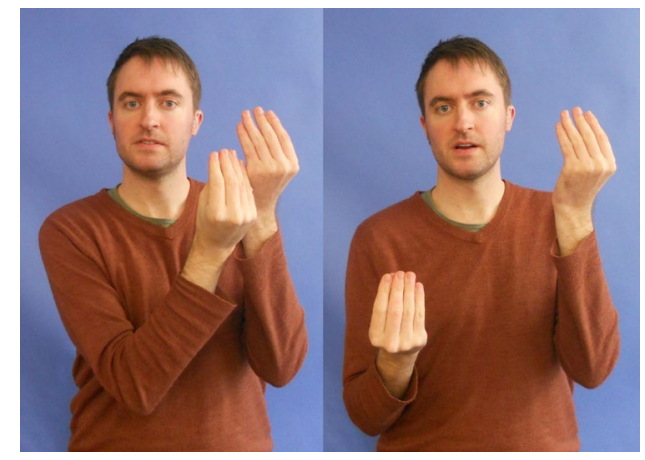

SAUDARA:1b

Figure 1. Two phonological variants meaning 'sibling(s)'

SAUDARA:1a and SAUDARA:1b differ only in terms of hand orientation: the former has a palm-down orientation, and for the latter the palm faces the signer; the locations and movement paths of both signs are identical, and differences between handshapes are phonetic. For this reason, the signs are considered to exhibit phonological variation.

Part of the section of data in which SAUDARA:1a and SAUDARA:1b occur is reproduced in Extract (1), along with a line drawing based on a frame from the data. Each time a sign is used for 'sibling', the variant is noted as either (1a) or (1b). Note that a sign name (SN) is a unique sign used to refer to a particular individual. 
(1)

\section{$(1)$}

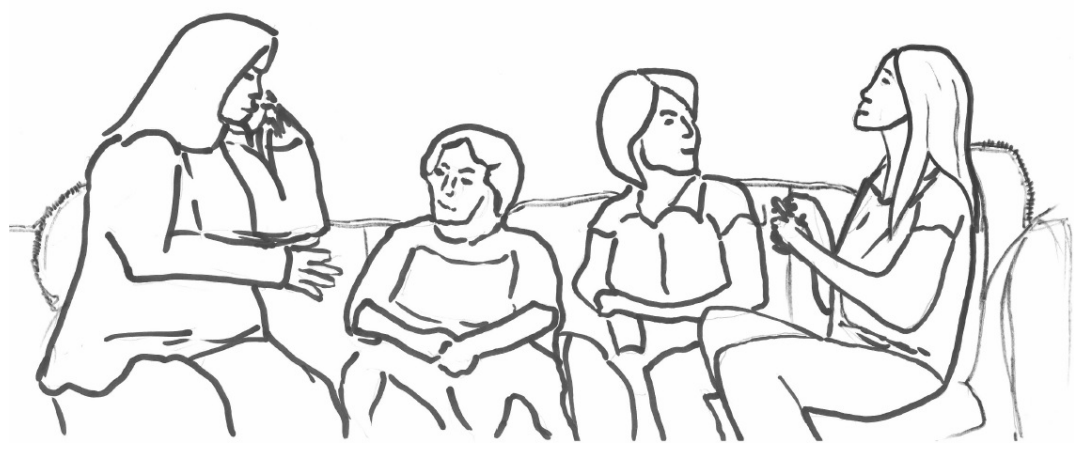

\section{Signer A}

(to all) My sibling (1b)

my eldest sibling (1b)

[SN]

moved and became

a teacher. She and her

husband have two children.

The second eldest...

$$
\begin{aligned}
& \text { (narrative continues, } \\
& \text { addressed to Signer B) }
\end{aligned}
$$

Signer B

Signer C
Signer D
Sibling (1b)... (turns to

face Signer D)

Who?

[Signer A] is talking

about her sibling (1a)

there, right? Because this

is my sign (1a), I've

never seen her sign (1b). (to Signer C) I don't know! I don't know! I have never met that person before. We live close to each other, that's good. [Signer A] can do as she likes.

Her signs are different. We are from Makassar, she's from Java.

The two articulations of SAUDARA:1b by Signer A (lines 1 and 2) take Signer C by surprise, and she immediately repeats the sign herself (line 2). An instance of schisming, where the conversation splits into two separate conversations (Egbert, 1997), is then initiated by Signer C in line 4: she turns to face Signer D and asks her a question, while A continues to address B. The timing of the schism is shown in (1) by a vertical dashed line.

Although the SAUDARA:1b variant is given social significance by Signers C and D, it does not seem to be unintelligible. Presumably the formal resemblance between the two phonological variants, along with contextual clues, enable a credible interpretation of Signer A's meaning. However, the variation triggers a series of broader metalinguistic comments which are issued by Signer D (lines 4-12 and 18-20) and implicitly endorsed by $\mathrm{C}$ (lines $15-17)$. These draw upon regional identity and invoke in-group/out-group distinctions (Gardner-Chloros, 2009, p. 56).

In her initial reaction to the question posed by Signer C (line 4), D indicates an unwillingness to consider what A has said, and underlines the fact that she and Signer $\mathrm{C}$ live close to each other (i.e., in the same city). The articulation of (1a) in line 14 is particularly interesting because Signer C stumbles over the production of this sign, initially using the hand orientation of $(1 \mathrm{~b})$. This production error might be taken to 
underline the striking resemblance between the two variants, since the variants are similar enough to allow for interference from (1b) during the production of target (1a). Signer D brings the discussion to a close by implying that (1a) is a Makassar variant and (1b) is a Javanese variant.

The way in which the schism grants Signers C and D 'cover', allowing them to construct and negatively evaluate signer A's variant even in her presence, is remarkable: occurrences of othering reported in the literature seem almost always to be targeted towards an 'absent member' or 'non-present group' (Mohammad \& Vásquez, 2015) whereas in (1) the target is present at the scene. The fact that signers A and B simultaneously hold a separate conversation enables signers $\mathrm{C}$ and $\mathrm{D}$ to conduct a scathing evaluation of signer A's variant without being detected, and this is also due in part to modality effects. While the risk of being overheard would be an ever-present consideration for speakers in such a situation, Signers C and D exploit the affordances of the visual-gestural modality, which requires signers to direct and focus their visual attention on a target signer in order to enable perception (Bouchard \& Dubuisson, 1995; Johnston, 1996).

In Extract (2), Signer D goes on to make the attack even more personal, describing the behaviour of A's husband (indicated by the use of his SN) as akin to that of a womaniser. This is expressed using a simple sign that has an $L$ handshape, which has the initial letter of a written word (the Makassarese term lale-lale, 'womaniser'). This term is also used as a simultaneous mouthing.

$\begin{array}{lcl} & \text { Signer A } \quad \text { Signer B } \\ 21 & & \\ 22 & \text { (conversation continues) } \\ 23 & \\ 24 & \\ 25 & \\ 26 & \end{array}$

\section{Signer C}

[Signer A] came here to get married.

\section{Signer D}

[Signer A] married. I hate SN [her husband], he's lale-lale. $\mathrm{SN}$ is lalelale. $\mathrm{SN}$ is lale-lale.

Because the term of insult used by Signer D is in the form of a 'single manual letter variant', deriving from contact with a spoken language, it is less 'iconic' than other signs that more openly or transparently reflect the meaning of the sign (see Taub, 2001). In addition, the concomitant mouthing 'lale-lale' is from Makassarese - a language that Signer A, as a newcomer to Makassar, does not know well, if at all. While it might seem incredible that Signer D says this while A is in the vicinity, it is likely that the relative inaccessibility of the insult - using a sign without visual meaning and a mouthing from a language unknown to $\mathrm{A}$ - persuaded her that it would pass undetected.

There is a key difference between the 'saudara' variants and traditional phonological variants for spoken languages in the Labovian tradition mentioned in Section 2. There is nothing in the phonological realisations of the SAUDARA variable that makes it inevitable as a trigger for the discourse observed in Extract 1. Unlike spoken languages, where one might expect a regional variant at the phonological level 
to occur across the phonological system, this example is isolated: there is no evidence to suggest that this phonological difference is generalised across a certain group of signs. That is, there is no set of signs articulated with a palm-back/pronated orientation in Java, which are articulated with a palm-down/forward orientation in Makassar. In this case, therefore, the phonological variation is exceptional rather than systematic, and the variable behaves more like what a sociolinguist of spoken languages would identify as a lexical variant. Indeed, this is one of the key reasons why much less work has been conducted on phonological and phonetic variation in signed languages compared with spoken ones.

What is important to note here is that phonological variants may still be perceived as such by signers. The variable (SAUDARA) becomes a marker in this context, and perhaps fleetingly so, not due to a general phonological property, but rather because of its perceived foreignness as a variant overall, and social meaning is attributed accordingly. This is very much in line with other third wave studies, where 'meanings of variables are not precise or fixed but rather constitute a field of potential meanings' (Eckert, 2008, p. 454). In Section 5, another example is presented of this kind of arbitrary and heavily contextualised interpretation, but this time the variant is lexical, and occurs as part of constructed action.

\section{Social meaning and variation in constructed action}

Constructed action is a discourse strategy widely used by signers (Cormier, Smith, \& Zwets, 2013). During CA, signers use their face, head, hands, body or other cues to represent, re-enact, perform, mimic or otherwise depict a referent's actions, utterances, feelings, thoughts or attitudes (Metzger, 1995). This may also entail reporting or 'quoting' a non-linguistic action (Hodge, Ferrara \& Anible, 2019). For constructed dialogues, which is essentially a subset of CA, a signer conveys what a referent said, or is imagined to have said, using various meaningful elements. In practice, the use of such dialogues may range from a single utterance to an extensive conversation. The roles that emerge in CA are created using combinations of linguistic and gestural features that may include changes in eye gaze, head or shoulder position, lexical signs, pointing signs, and qualitative or creative aspects of performance, such as mimicking the mannerisms and facial expressions of the referent they are enacting (see Ferrara \& Johnston, 2014, for a description of CA in Australian Sign Language). In so doing, signers create a 'pretend world' in which various referents interact with each other, and in identifying this, the viewer reads the utterance as constructed action. A very simple example would be an enacted parent-child dialogue, where each role is created using combinations of head position (tilting upwards for the child, downwards for the parent), facial expressions, lexical and grammatical variants, and gestures. In this example, the direction and angles of pointing signs might also match the role. 
One notable feature of $\mathrm{CA}$ is that it becomes possible for a signer to recruit certain variants into the enactment instead of others, and capture the delivery style of an utterance as well as the content. This requires impressive skills; the signer needs to know much about language, culture and society to do this effectively. Such behaviour has been noted in spoken languages too, in enacted dialogues, where storytellers capture the delivery style of an utterance as well as the content; Bakhtin (1981) refers to the notion of 'voicing' as the performative element of quotation. For sign languages, such performance may include visual 'tone of voice' and other mannerisms. Some signers are talented imitators, able to play with such details to construct a rich and engaging retelling of a dialogue, sometimes for comic effect. Importantly, the reproduction of delivery style is optional, rather than compulsory, and given the potential for variation in their construction (in terms of content and performance), these dialogues should be of particular interest to sociolinguists looking for linguistic variables.

In what follows, two examples of CA are analysed to determine how the variables in question create social meaning. In Example II, Ari indicates a negative evaluation of a sign used in a different region, while in Example III Ambar uses CA to index deaf and hearing roles.

\section{Example II: Ari (Solo)}

Ari and Lilik are two deaf men in their 20s who live and work in Solo and often play football for the Solonese deaf team. In the course of their conversation, Ari reports a dialogue between two other people, in which one of them - referred to here as Susilo is asked whether he will join them in a football match with a team from the neighbouring city of Yogyakarta. Susilo replies that he will not (3).

\begin{tabular}{l|llll|lll} 
SN:SUSILO & $\begin{array}{l}\text { FUTSAL } \\
\text { football }\end{array}$ & join & FUTSAL & SN:YOGYA & SN:SUSILO & NOT:asl & $\frac{t g}{\text { NOT:asl }}$ \\
Susilo & football & Yogya & Susilo & NOT:asl & NOT:asl
\end{tabular}

Susilo was asked 'Are you joining us in Yogyakarta for the football? He said 'No! No!'

In reproducing Susilo's reply, Ari does not use TIDAK, the negative particle that he and other Solonese deaf people use routinely. Instead, he uses a lexical variant which I gloss as NOT:asl because it originates from American Sign Language (Palfreyman, 2015, p. 202). Each of the two consecutive tokens of NOT:asl in Ari's utterance is accompanied by an idiosyncratic non-manual marker comprising an exaggerated protruding tongue $(\mathrm{tg})$. Both TIDAK and the articulation of NOT:asl with non-manual markings are shown in Figure 2. 


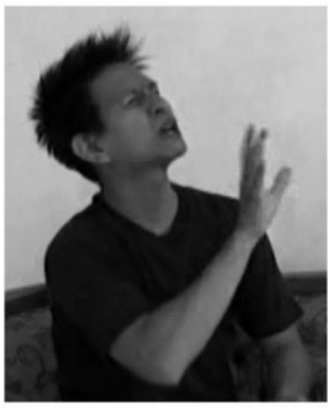

TIDAK
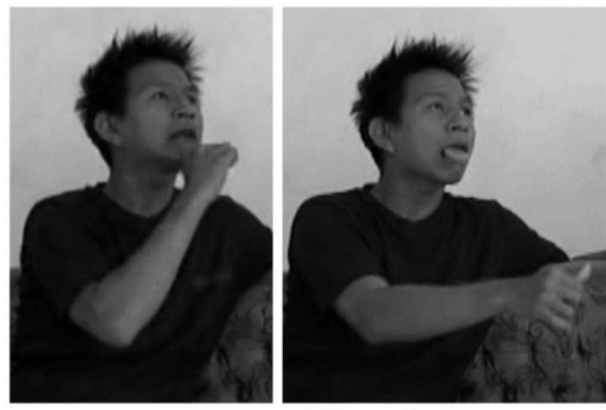

NOT:asl

Figure 2. Lexical variants for negative interjection ('no')

Use of the NOT:asl variant is uncommon in Solo, but Susilo has spent many years in the city of Surabaya, East Java, where ASL is reported to have exerted considerable influence on the lexicon (Palfreyman, 2016, p. 268).

In reporting this conversation between two third parties, it is highly likely - though of course impossible to verify - that Ari is producing exactly the manual form that he originally observed Susilo using. The way that Susilo's response is reported constitutes an 'unexpected' practice in the narrative (Ochs, 2004; Ochs \& Capp, 2001), the evaluation of which is revealing for what it says about social identification. Crosslinguistically, the protruding tongue is reported to have a negative or pejorative association (see Lewin \& Schembri, 2011, for an overview); in the BISINDO corpus there are instances where this non-manual feature specifies carelessness or lack of refinement; and Luztenberger (2017) posits an association between tongue protrusion and negative evaluation in Kata Kolok (a village sign language used in north Bali, see Mudd et al, this issue).

Given that Ari and Lilik both know Susilo, who is known to use ASL forms that are common to Surabaya, it would seem that Ari adds the exaggerated non-manual form to indicate his own negative evaluation of Susilo's variant NOT:asl. In other words, Ari's skill in performing enactment is important because it enables him to reproduce the form of what was said by Susilo, while tailoring his own personal evaluation of Susilo through his use of non-manual features: the result is a parody of Susilo's utterance. This is perhaps akin to examples of enacted dialogue reported by Jaworski and Coupland (2005), where English speakers are creative in voicing others, for instance by switching between Welsh and RP accents as they quote dialogue.

The evaluative element of Ari's reconstruction is curious, and raises the question of whether an identity is being indexed. Neither he nor Lilik use NOT:asl on a daily basis, which evokes an immediate 'us/them' distinction not dissimilar to the ones expressed by the Makassarese signers in Example I. Although the occurrence of NOT:asl is uncommon within the Solonese sign community, other ASL variants - meaning 'try', 'ordinary' and 'parents' - are sometimes produced by Solonese men who have previously spent time working in Surabaya (Palfreyman, 2019, p. 63). This begs the question of why NOT:asl attracts Ari's disdain. 
Certain signs are referred to by some Indonesian signers as isyarat lama, 'old(er) signs' that have often been displaced by more recent ones (Palfreyman, 2019, p. 286). Despite the fact that some ASL variants are also used by some Solonese signers, there is also an acute perception of lexical differences between Javanese cities, and in the minds of some signers, variants become aligned with cities. In the case of Solo and Surabaya, variants of ASL origin are often linked with the latter, while isyarat lama are associated with Solo. This was confirmed by a conversation I observed with a Surabayan deaf man, who spent 30 minutes identifying Surabaya-Solo oppositions for different

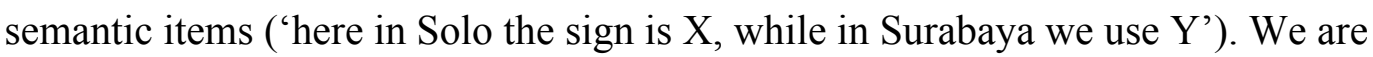
therefore faced with several possible interpretations for Ari's evaluation - including that Ari has a personal issue with Susilo; and that Ari's negative evaluation is motivated by larger ideological issues towards signs (or signers) from Surabaya. ${ }^{3}$

In Examples I and II, signers face variants that are not indigenous to their own city or region. In neither case does this pose a barrier to intelligibility, but in both cases, signers skilfully seize upon these differences and add embellishment, imbuing them with social significance. These flashpoints are important in what they reveal about regional identities and provide further evidence of the differences that signers themselves identify in their discourse.

\section{Example III: Ambar (Solo)}

Another example of socially meaningful variation can be found in a narrative told by Ambar, who also comes from Solo. She tells her friend Arie about her previous experiences of looking for a job, trying several different professions before finding the one that was right for her. During the course of little over two and a half minutes of conversation, she negates the modal predicate bisa ('can') ten times, and these tokens fall into two types. These types are introduced below, along with a brief discussion of their origins and patterns of use, which is important in order to understand how Ambar uses them to produce social meaning.

The most common type of negative construction in the BISINDO Corpus employs a manual negative particle, TIDAK (Palfreyman, 2019). Where this particle is used to negate a predicate, the predicate may be expressed manually in sequence, or by using a simultaneous mouthing (Palfreyman 2019, p. 204). The latter variant is referred to here as a 'mouthed predicate' construction. An example is shown in (4), where the predicate 'want' (Indonesian: mau) is negated using the mouthing 'tidak mau' (which means 'not want').

$$
\text { PT:PRO1 } \frac{\text { tidak mau }}{\text { TIDAK }}
$$

I don't want [to do it].

\footnotetext{
${ }^{3}$ An additional possibility is that, while 'othering' Susilo through constructed action, Ari is able to increase his cultural capital with Lilik by demonstrating his sign language skills in using CA and simultaneous non-manual features so effectively.
} 
In addition to mouthed predicate constructions, there is a distinct manual suppletive form (TIDAK-BISA) meaning 'cannot', which grammaticalized from a sign meaning 'difficult' (Palfreyman, 2019, p. 70). These are regarded as grammatical variants because they constitute semantically and functionally identical yet morphosyntactically different means of negating the same predicate (see Palfreyman, 2019, pp. 207-215).

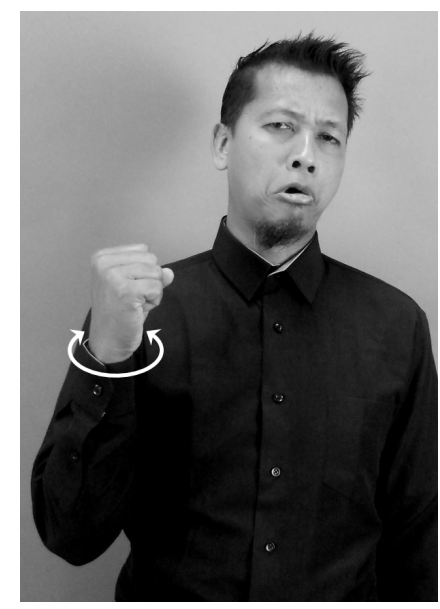

TIDAK-BISA (negative suppletive, citation form)

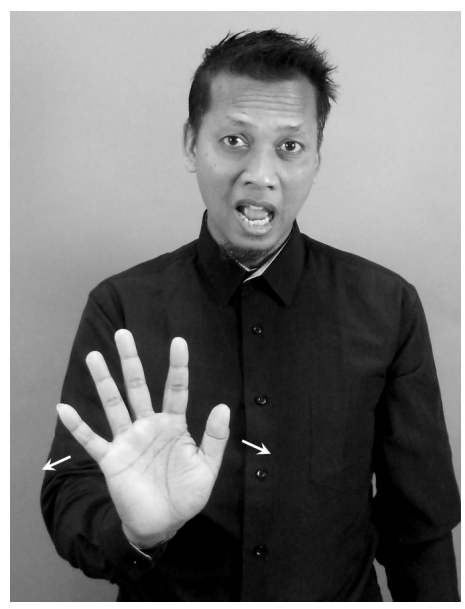

TIDAK (negative particle, citation form)

Figure 3. Manual forms for two grammatical variants meaning 'cannot'

The citation form for each variant is shown in Figure 3. For the analysis in Palfreyman (2019), 808 instances of negation were coded according to the type of grammatical variant. Of 78 tokens where the predicate 'can' is negated, 52 tokens are suppletive in type (TIDAK-BISA), with 22 tokens of mouthed predicate constructions of the kind shown in (5). For the remaining four tokens, the predicate is negated sequentially with TIDAK.

\begin{tabular}{rlll} 
gesture & & \multicolumn{2}{c}{ TIDAK--------- } \\
speech & saya & tidak & bisa \\
translation & I & NEG & can \\
meaning & 'I cannot.' &
\end{tabular}

The negative particle TIDAK is of gestural origin (Palfreyman, 2019, p. 187), and is sometimes used by Indonesian speakers as a co-speech gesture to accompany negative constructions. In particular, the 'TIDAK with mouthed predicate' construction has very clear parallels with the constructions that deaf signers can observe in production by hearing speakers (5), even if over time the mouthings have sometimes become reduced. Conversely, as pointed out above, TIDAK-BISA has its origins elsewhere in the sign language, and does not come from co-speech gesture. Across instances of grammatical negation in the corpus, Palfreyman (2019) finds that older signers favour the use of 
negative particles (such as TIDAK), while younger signers favour negative suppletive variants such as TIDAK-BISA, where they are available. This in turn suggests that, over time, BISINDO is using more irregular forms of negation (Palfreyman, 2019, p. 234).

Returning to Ambar's narrative, in which she discusses her search for the right job, Table 1 shows 10 tokens meaning 'cannot', which occur within a 160-second stretch of data.

Table 1. Instantiations of the variable (cannot) produced in the roles 'Ambar' and 'Ambar's older sister' during a stretch of narrative

\begin{tabular}{|c|c|c|c|c|}
\hline \multicolumn{2}{|c|}{$\begin{array}{l}\text { Token reference number } \\
\downarrow\end{array}$} & \multirow{2}{*}{$\begin{array}{c}\begin{array}{c}\text { role: Ambar } \\
\text { (deaf) }\end{array} \\
\text { TIDAK-BISA }\end{array}$} & \multirow[t]{2}{*}{$\begin{array}{l}\text { role: sister } \\
\text { (hearing) }\end{array}$} & \\
\hline 1,2 & I said, 'I cannot, sorry, I cannot sew'. & & & \\
\hline 3 & I tried to cut someone's hair, I said, 'I cannot do this'. & TIDAK-BISA & & \\
\hline 4,5 & I said, 'I cannot do make-up, and I cannot cut hair'. & TIDAK-BISA & & \\
\hline 6 & I said, 'Yes, because I cannot cut hair'. & TIDAK-BISA & & \\
\hline 7 & I asked, 'Can I go elsewhere?' She replied, 'You cannot'. & & TIDAK/'tidak bisa' & narrative \\
\hline 8 & For Rp. 100.000 a month, I could not go anywhere. & TIDAK-BISA & & \\
\hline 9 & I asked, 'Can I have Rp.150.000?' She replied, 'You cannot.' & & TIDAK/'tidak bisa' & \\
\hline 10 & She said, 'You could make porridge.' I said, 'I cannot do that!' & TIDAK-BISA & & \\
\hline
\end{tabular}

Importantly, all but one of these (token 8) occur during constructed dialogue. (In Indonesian and in BISINDO, tense is not expressed grammatically, so the variable applies both to 'cannot' and 'could not'.) Ambar uses constructed dialogue to recreate an ongoing conversation that she had with her older sister and with other unspecified hearing people, none of whom use BISINDO. Eight of the tokens are suppletive (TIDAK-BISA), while two are mouthed predicate constructions (TIDAK with 'bisa' as a simultaneous mouthing).

In this stretch of narrative, both of the mouthed predicate constructions occur in the role of Ambar's older sister, while the suppletive tokens occur in the role of Ambar. It is perhaps not surprising that a signer should associate a different variant with each role, as this reinforces the distinction between the two roles. However, given what is known about the origins of these signs - the gestural origins of the mouthed predicate construction, and the language-internal origins of the suppletive - an additional perspective emerges. Although such an ideology has not been overtly expressed by BISINDO users, I suggest that the suppletive variant is more 'deaf' than the mouthed predicate construction, which is more 'hearing' because of its gestural associations.

It seems that Ambar is using variation to colour the performances of the two roles, making a differentiation between Ambar, as a young deaf sign language user, and her older hearing sister, who does not sign. The likelihood of this interpretation is strengthened by the switches back to the suppletive variant for token 8, when Ambar expresses the variable 'as herself' (outside of the constructed dialogue), and again, in character as herself, for token 10. 


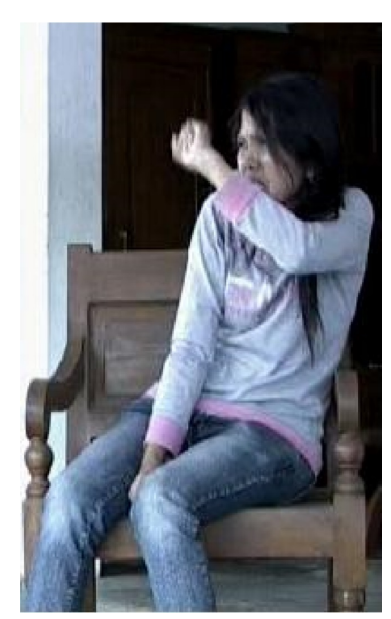

TIDAK-BISA

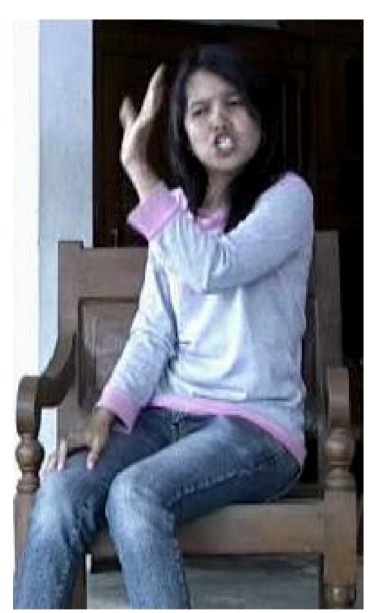

TIDAK + mouthing 'tidak bisa'

Figure 4. Two grammatical variants with which Ambar negates the predicate 'can' during the dialogue presented in Table 1. Note how differences in head position also mark the two roles.

The conclusions reached in Example III are borne out by statistical analysis. In Palfreyman (2019, p. 233), 770 tokens of grammatical negation were coded according to whether or not they are situated in constructed dialogue. The 162 tokens that do occur in constructed dialogue, were further coded according to whether the role is deaf $(n=116)$ or hearing $(n=46)$. Mixed effects variable rule analysis (Rbrul, Johnson, 2009) was used to see whether this factor group favours the production of the mouthed predicate construction. Constructed action is found to be statistically significant for this variable $(d f=5 ; p=0.0016$; see Table 2$)$.

Table 2. Rbrul findings for the selection of TIDAK with mouthed predicate constructions. The table shows the factor found to be statistically significant (constructed action). Other factors included in the run are the region, sex and age of the signer.

\begin{tabular}{|c|c|c|c|c|}
\hline Deviance & \multicolumn{4}{|c|}{677.813} \\
\hline DF & \multicolumn{4}{|l|}{5} \\
\hline Grand mean & \multicolumn{4}{|l|}{0.173} \\
\hline Application value & \multicolumn{4}{|c|}{ TIDAK with mouthed predicates } \\
\hline Total $(\mathbf{N})$ & \multicolumn{4}{|l|}{770} \\
\hline Factors & L-O & $\%$ & $\mathbf{N}$ & CFW \\
\hline $\begin{array}{l}\text { Constructed action } \\
\text { reported (hearing) } \\
\text { reported (deaf) } \\
\text { not reported }\end{array}$ & $\begin{array}{r}0.664 \\
-0.032 \\
-0.632\end{array}$ & $\begin{array}{r}(\mathbf{p}= \\
37.0 \\
22.4 \\
14.8 \\
\text { ran }\end{array}$ & $\begin{array}{c}016) \\
46 \\
116 \\
608 \\
31\end{array}$ & $\begin{array}{l}0.660 \\
0.492 \\
0.347\end{array}$ \\
\hline
\end{tabular}

Contexts where the utterance of a hearing person is reconstructed are found to favour the use of the mouthed predicate construction (factor weight $=0.660$ ), while contexts 
where the utterance of a deaf person is reconstructed slightly disfavour this paradigm (0.492).

I hypothesise therefore that the hearing status of the person whose utterance is being constructed may affect the realisation of the variable therefore has statistical support. It seems that this is due to the fact that, of all the grammatical variants available for negating a predicate in BISINDO, mouthed predicate constructions are the closest to the gestural construction shown in (5). In turn, this gives further evidence in favour of the idea that, in this example, grammatical variants are imbued with social meaning. Recalling the importance of styles in third wave research, it is not yet clear how such personae are created in sign languages, but the differentiated deaf and hearing roles in Example III could tentatively be regarded as personae: 'the young deaf signer' and 'the hearing gesturer'. More work is needed to see how such personae are substantiated in the sociolinguistic practices of signers, although a tentative case is made in section 6 for another persona - 'the oral deaf person' - using mouthings.

\section{Creating social meanings from mouthings}

The use of mouthings in sign languages was mentioned briefly in Section 4, and we have already noted that a signer in Makassar uses a mouthing from a local language (Makassarese) as well as from Indonesian. Not all signs are accompanied by mouthings, and some sign languages seem to use mouthings more than others. There is also considerable variation among signers, and for BISINDO - as with other sign languages - there seems to be a correlation between mouthings and education level (Fontana, 2008; Hohenberger \& Happ, 2001). For instance, one signer in the BISINDO corpus did not have the opportunity to enter formal education, and this helps to explain why she uses very few mouthings. Mouthings may also have a practical function as a strategy in facilitating mutual intelligibility when signers face unfamiliar manual variants (Eichmann, 2008).

The extent to which mouthings are used is clearly a marker of identity for some signers. Given the contact that may occur between a signed and spoken language, utterances can be placed along a continuum showing influence from the respective grammars of the two (Palfreyman, 2015, p. 6). In British Sign Language (BSL), for example, one who mouths well-formed English sentences while signing would be perceived by some as committing to an identity that is less culturally deaf. Anecdotally, the language of those who form this perception is typically more sparing in the prevalence of mouthings, and the mouth may be reserved more for other forms, such as the expression of mouth gestures.

Perceptions of the mouthing parameter can be observed in situations where the maintenance of a distinction between BSL and English is regarded as important, for example in a BSL class, where a teacher might advise a learner to make their signing 'more BSL' by using less mouthing. In the BSL situation comedy Small World (first screened on the online BSL Zone portal in 2014), the signing of one of the deaf 
characters, Laura, clearly features more English mouthing than others. This is used to index an 'oral' persona (where a deaf person has had little or no sign language contact during their upbringing) and this fits in with the story that Laura is a relatively new entrant to what Lane (2005) terms the 'Deaf-World'.

Since mouthings derive from contact with spoken languages, the question arises of what happens in situations where more than one spoken language is used. In India and Pakistan, for example, signers sometimes use mouthings from several languages (Zeshan, 2001), while some New Zealand Sign Language users also use mouthings from Māori in addition to English (McKee, 2019). Given the number of spoken languages in Indonesia, there may be many examples of this kind of code-switching, and the rest of this section focuses on the sociolinguistic practices of deaf signers in Java, and in particular the city of Solo.

\section{Example IV: Code-switching in the mouthings of Javanese signers in Solo}

Even a cursory look at mouthings in the BISINDO Corpus reveals that almost all of those that occur in Solo are from Indonesian. However, some mouthings are from Javanese, which is used by 75-80 million Indonesians, making it the largest Austronesian language by far in terms of first-language speakers (Sneddon, 2003, p. 25). In examples (6) and (7), mouthings sit on the top line. Javanese mouthings are in bold type, and represent the way the words appear on the lips, rather than how they are conventionally spelt in the literature. All other mouthings are from Indonesian.

\begin{tabular}{|c|c|c|c|c|c|}
\hline ada & masalah & menipu & bohong & dolan & masalal \\
\hline $\begin{array}{l}\overline{\mathrm{ADA}} \\
\text { existential }\end{array}$ & $\begin{array}{l}\overline{\text { MASALAH }} \\
\text { problem }\end{array}$ & $\begin{array}{l}\text { MENIPU } \\
\text { cheat }\end{array}$ & $\begin{array}{l}\text { BOHONG } \\
\text { lie }\end{array}$ & $\begin{array}{l}\overline{\text { JALAN-JALAN }} \\
\text { go-about }\end{array}$ & $\begin{array}{l}\text { MASALAF } \\
\text { problem }\end{array}$ \\
\hline
\end{tabular}

'There are problems. [The board members] cheat, lie, go about town. There are problems.'

\begin{tabular}{ll|l|l|l}
$\frac{\text { malas }}{\text { MALAS }}$ & $\begin{array}{l}\text { tul } \\
\text { BETUL } \\
\text { right }\end{array}$ & $\begin{array}{l}\text { SMS\#TERUS } \\
\text { sms (continuous) }\end{array}$ & $\begin{array}{l}\text { RINDU } \\
\text { miss }\end{array}$ & $\begin{array}{l}\text { opo } \\
\text { PALM-UP }\end{array}$ \\
lazy & NEG
\end{tabular}

'You were being lazy, right? Always texting [him], missing [him] - how come?!'

A selection of Javanese mouthings from the corpus is shown in Table 3. These largely fall into the domains of daily activities and objects ('eat', 'bathe', 'go out and about', 'money'), discourse markers ('never mind', 'thank you'), interrogatives ('what', 'who', 'how'), responses ('already') and numerals (wolu 'eight', rolas 'twelve').

It is unsurprising that mouthings fall into these domains, because Javanese is used in the home, and so deaf Javanese people become familiar with the isolated words visible on the lips of their parents, grandparents and older siblings. However, in schools for deaf children in Indonesia, great emphasis is placed upon the acquisition of Indonesian 
at the expense of other regional and local languages (Branson \& Miller, 2004), and deaf children become very familiar with Indonesian at the expense of Javanese.

Table 3. A selection of Javanese mouthings (bold type) that occur in the BISINDO Corpus, alongside translations into Indonesian (italic type) and English. Words in bold type represent the way the Javanese word appears on the lips, rather than the conventional spelling in the literature.

$\begin{array}{llllll}\text { wis } & \text { sudah } & \text { already } & \text { wolu } & \text { delapan } & \text { eight } \\ \text { piye } & \text { bagaimana } & \text { how (come) } & \text { rolas } & \text { duabelas } & \text { twelve } \\ \text { opo } & \text { apa } & \text { what } & \text { limolas } & \text { limabelas } & \text { fifteen } \\ \text { sopo } & \text { siapa } & \text { who } & \text { asu } & \text { anjing } & \text { dog (offensive) } \\ \text { ora opo-opo } & \text { tidak apa-apa } & \text { never mind } & \text { goblok } & \text { bodoh } & \text { stupid } \\ \text { dhewe } & \text { diri } & \text { self (reflexive) } & \text { dhuit } & \text { uang } & \text { money } \\ \text { dolan } & \text { jalan-jalan } & \text { go around } & \text { thok } & \text { saja } & \text { that's all }\end{array}$

Crucially, when a signer in the corpus uses a Javanese mouthing, they may also use the Indonesian equivalent. That means the practice is not referential, for this is not 'the phenomenon of the most available word' (Grosjean, 1982, p. 125). In other words, we can reject the possibility that a younger Solonese signer is using Javanese mouthings because there is no equivalent Indonesian word, or because they cannot think of an equivalent term.

For example, (8) and (9) are parallel phrases with the same meaning, produced within five seconds of each other by a 53-year-old woman in Solo. The sign MENJADIDEWASA (become older) is produced twice, and followed each time by SUDAH:3, a completive particle. Yet the Indonesian mouthing 'sudah' is produced in (8), and the Javanese mouthing 'wis' is used in (9).

$\begin{array}{ll}\text { MENJADI-DEWASA } & \begin{array}{l}\text { SUdah } \\ \text { SUDAH:3 } \\ \text { completive }\end{array}\end{array}$

'He is already an adult now.'

(9)

\begin{tabular}{|c|c|c|c|}
\hline & dak boleh & & wis \\
\hline VCD & TIDAK & MENJADI-DEWASA & $\overline{\text { SUDAH:3 }}$ \\
\hline $\mathrm{CD}$ & NEG & become-older & completive \\
\hline
\end{tabular}

Given that signers know equivalent terms in both languages, why does this switching take place? And how can we be sure that this code-switching has social meaning? It could be that signers are not attuned to the difference in language, and regard the choice as inconsequential. In (8) and (9), for example, the choice of 'sudah' or 'wis' might simply be free variation. 
In fact, signers appear to be highly sensitive to the use of Javanese mouthings, in ways that suggest that the phenomenon is well above the level of awareness. Since I am fluent in Indonesian, and have acquired a limited set of Javanese words which approximates that of my local interlocutors, I am able to control my use of mouthings and observe any effects that result from switching between spoken languages. On many occasions I have seen that if, as a foreigner, I drop a Javanese mouthing into a conversation with a new acquaintance, my interlocutor will invariably be surprised, stop the conversation immediately, and note that I know Javanese, sometimes asking how it is that I know that word. This suggests that switching to Javanese is not simply a case of using inconsequential alternative, but rather is a socially significant practice.

Javanese identity is particularly strong in Solo, which along with Yogyakarta is an exemplary and historic centre of Javanese culture (Errington, 1985; Vander Klok, 2012, p. 17). The varieties of Javanese used in these two cities are considered to be standard, and although Javanese culture is expressed through several means, including costume, dance and music, fluency in Javanese is one of the key ways of indexing one's Javanese identity. Since 'being Javanese' is perceived as important - especially in Solo - and given that Javanese is used by much of hearing Solonese society, it is unsurprising that deaf signers also use language to 'be Javanese', employing the practice of Javanese mouthings to index a Javanese identity.

The reinforcement of group identity through the use of Javanese mouthings creates an us/them distinction (Gumperz, 1982): the out-group comprises those who are not ethnic Javanese, regardless of hearing status. The fact that the Javanese identity is common to both deaf and hearing people means that this identity cross-cuts through the prominent deaf-hearing social divide, thus complexifying the traditional deaf-hearing distinction prevalent in the literature (Ladd, 2003; Padden \& Humphries, 2006; Van Cleve \& Crouch, 1997). It is of course understandable that early lines of enquiry in deaf studies and sociolinguistics focused on the deaf-hearing divide; the argument here and elsewhere (e.g., Kusters \& Friedner, 2015) is that we now need to look beyond this divide to examine complex and intersecting identities.

The finding here is very much in line with those of the other examples considered above: that sub-identities exist within the deaf sign community in Indonesia, some of which cut across the boundaries of hearing status and language modality; and that signers should be regarded as agents in order to uncover what will ultimately resemble a complex web of social indices. In the concluding section I reflect on the challenges that sociolinguists face in seeking to apply social constructionist approaches to sign communities.

\section{Conclusions and challenges}

This article represents an attempt to apply social constructionist methods of sociolinguistic research to sign languages, mining the BISINDO Corpus for moments where signers use language variation to create social meaning. The endeavour has 
resulted in four examples where signers use this variation for different purposes. The resulting analysis reveals some early answers to the questions of what insights can be gleaned from such examples, what challenges emerge when seeking to apply methods associated with the third wave to sign languages, and how these challenges can be handled.

First, on the question of where socially meaningful variation is to be found in signed languages, it is clear that this kind of variation can occur at different levels of linguistic organisation, including not only the lexical but also the grammatical levels, and in non-manual channels. From this study, it seems that certain parts of the language may be of considerable interest to those interested in variation as a practice linked with social identification. Occurring with regularity across the BISINDO corpus, instances of constructed action are a very good place to look for variables because effective use of enactment presents signers with choices concerning how to represent information, which must often be taken in light of nuanced differences in the way that people sign.

Language contact phenomena such as mouthings also merit consideration, because signers must choose how and how far to represent spoken languages on the lips (from mouthing to no mouthing, or somewhere in between). Especially in cases where the ambient speech community uses more than one spoken variety, we have seen that a signer's representation of mouthings from different spoken languages may also carry social significance (Section 6).

There is also evidence to suggest that the provenance of variants may have some bearing over how the use of the variant is to be interpreted. The ASL origins of a variant reproduced by Ari (Example II) appears to be relevant to the social meaning attached to its use. Similarly, both variants that occurred in Ambar's narrative (Example III) are used by members of the sign community, but one clearly resembles an utterance of a hearing non-signer (a conventionalised co-speech gesture), while the other variant, a negative suppletive, emerged within BISINDO and is favoured by younger signers.

Having considered the forms or features that are used to express identities, we can then look at the social meanings that are created. Variation is used to reinforce regional identity (Example I), perhaps to comment on the influence of ASL (Example II), to distinguish between deaf and hearing roles (Example III), and to index a Javanese identity (Example IV). In the latter example, we can see just how identity becomes more complex than previously supposed: ethnic Javanese identity is indexed by hearing speakers and by deaf signers, creating a local social category that creates affinity between deaf and hearing Javanese against non-Javanese, regardless of hearing status. The notion that identities occur along modality lines (signers vs. speakers) therefore ignores a potentially huge and complex web of social identities that exist within sign communities in Indonesia and around the world.

How do examples of socially meaningful variation from the BISINDO corpus accord with categories that have emerged in spoken language sociolinguistics? Sociolinguists of spoken languages have recently paid considerable attention to style, but it is not yet clear how examples presented here relate to stylistic practices, or the 
creation and use of personae. Only briefly has it been possible to consider variants, tentatively, as revealing personae such as 'the young deaf signer', 'the hearing gesturer' and 'the oral deaf person'. Further work is needed in order to build on the examples studied above, which are isolated incidents; only through more extensive studies will it be possible to produce analyses of style in sufficient depth and detail.

In seeking to analyse socially meaningful variation, several major challenges emerge. Firstly, despite our increasing knowledge of sign languages, gaps remain in our understanding of how sign languages work, and this impedes our ability to interpret sign language data as sociolinguists (Lucas \& Bayley, 2016). Much remains to be discovered too about the components of communicative strategies and how they might combine, which is particularly important, for example, when considering styles. Sociolinguists of sign languages must train the eye to observe constellations of features, strategies and heuristics that might point to social meanings, and as with spoken languages, this requires an ethnographic approach - time spent with sign community members pays off in this regard, as in others. Perusing recordings of signed conversations alongside members of the community is also an effective way to analyse the data, by inviting comments and judgements, and by probing for possible (social) meanings.

A second challenge is the need for in situ or socially-situated texts (Gumperz, 1982). The well-resourced sign language corpora that have been created (for BSL, Sign Language of the Netherlands, and German Sign Language, among others) tend to prioritise the recording of data that are of high technical quality, with professional lighting and the use of multiple camera angles to capture the full range of movement and expression (Palfreyman, in press). This is obviously important for detailed linguistic analysis, but in practice it usually means that signers have gathered in permanent or temporary sign language laboratories. Even though efforts are often made to collect data in different regions, filming inevitably takes place in one or two artificial venues in each region to enable the use of equipment and so on. The risk is that, when signers are removed from familiar surroundings, the sociolinguistic patterns of the language that they produce are suppressed, or not as manifest as they would usually be.

The recent growth of linguistic anthropologists incorporating ethnographic approaches into their research suggests that the field may be rebalancing itself, although it is notable that most of the studies using in situ recordings focus on the global South (Hou, 2016; Kusters, 2017; Moriarty-Harrelson, in preparation; Reed, this issue). In terms of rooting out socially-sensitive variables, data recorded in the home of a signer or at a social gathering, while perhaps of less visual clarity, may render considerably more social meaning, though of course this kind of data raises significant ethical issues (Palfreyman, in press).

Finally, there may be some difficulty in collecting metalinguistic judgements, ideologies or language attitudes from sign language users. This is a challenge that any linguist may face, and is not exclusive to sign language research, but at times it has been taxing when looking at social meaning in the BISINDO corpus. Many members of the Indonesian deaf community are still unaware that they are using a sign language, or do 
not yet understand the implications of this (Palfreyman, 2019). As a result, the metalinguistic awareness of signers is often quite low, and self-reflection or speculation on the use of language is not always easy to facilitate. In some situations, it is a matter of finding the right question to ask, but in others the kinds of comments that might corroborate a hypothesis might simply be unavailable. If this is the case, there are perhaps other strategies, such as creating situations to stimulate responses that can be more easily observed (as in the example of an outsider using Javanese mouthings, in section 6), but the 'perfect' corroborating comment may still remain frustratingly elusive.

In spite of these challenges, the findings presented in this article suggest that the application of multiple analytic practices from all three waves of sociolinguistics have much to offer, leading to a clearer picture of how signers express social meaning through variation. The application of these practices to sign languages enriches the field of sociolinguistics as a whole; while for those seeking a deeper understanding of sign languages, fresh insights on the linguistic and social dimensions of sign language variation become apparent.

\section{Acknowledgements}

I am deeply indebted to deaf community members in Indonesia who supported this research in different ways and shared their experiences, especially Muhammad Isnaini, Dwi Maryamah, Oktaviany Wulansari, Jayeng Pranoto, Haji Ramlah and Pak Iwan. This article has benefitted considerably from helpful comments and feedback given by Gab Hodge, Hanna Jaeger, Hannah Lutzenberger, and three anonymous peer reviewers. I am very grateful for their generous support and encouragement. I would like to acknowledge a number of conversations on themes discussed in this article with Tom Conners, Kearsy Cormier, Connie de Vos, Annelies Kusters, Noor Malihah, Rachel McKee, Miriam Meyerhoff, Victoria Nyst, Adam Schembri, Rose Stamp and Ulrike Zeshan. I acknowledge too the support of the Leverhulme Trust in granting Early Career Research Fellowship ECF-2016-795, without which this research would not have been possible.

\section{References}

Agha, Asif (2003). The social life of cultural value. Language and Communication, 23, 231273.

Antaki, Charles, \& Widdicombe, Sue (Eds.) (1998). Identities in talk. London: Sage Publications.

Bakhtin, Mikhail M. (1981). The dialogic imagination: Four essays by M.M. Bakhtin (Michael Holquist, Ed., Caryl Emerson \& Michael Holquist, trans.). Austin, Texas: University of Texas Press. 
Bertrand, Jacques (2003). Language policy and the promotion of national identity in Indonesia. In Michael E. Brown \& Sumit Ganguly (Eds.), Fighting words: Language policy and ethnic relations in Asia (pp. 263-290). London: MIT Press.

Bienvenu, Martina J. (1991). Can deaf people survive "deafness?" In Mervin D. Garretson (Ed.), Perspectives on deafness: A deaf American monograph (pp. 21-28). Silver Spring, MD: National Association of the Deaf.

Bouchard, Denis, \& Dubuisson, Colette (1995). Grammar, order and position of Wh-signs in Quebec Sign Language. Sign Language Studies 87, 99-139.

Boyes Braem, Penny, \& Sutton-Spence, Rachel (Eds.) (2001). The hands are the head of the mouth: The mouth as articulator in sign languages. Hamburg: Signum Press.

BPS (Badan Pusat Statistik) [Indonesian Statistics Bureau] (2019). Statistik Indonesia 2019 [Statistical Yearbook of Indonesia 2019]. Retrieved 15 June, 2019, from www.bps.go.id

Branson, Jan, \& Miller, Don (2004). The cultural construction of linguistic incompetence through schooling: Deaf education and the transformation of the linguistic environment in Bali, Indonesia. Sign Language Studies, 5(1), 6-38.

Bristowe, Anthea, Oostendorp, Marcelyn, \& Anthonissen, Christine (2014). Language and youth identity in a multilingual setting: A multimodal repertoire approach. Southern African Linguistics and Applied Language Studies, 32(2), 229-245.

Bucholtz, Mary (1996). Geek the girl: Language, femininity, and female nerds. In Natasha Warner, Jocelyn Ahlers, Leela Bilmes, Monica Oliver, Suzenne Wertheim, \& Melinda Chen (Eds.), Gender and belief systems: Proceedings of the Third Berkeley Conference on Women and Language (pp. 119-131). Berkeley, CA: Berkeley Women and Language Group.

Bucholtz, Mary \& Hall, Kira (2004). Theorizing identity in language and sexuality research. Language in Society, 33(4), 469-515.

Cameron, Deborah (2000). Styling the worker: Gender and the commodification of language in the globalized service economy. Journal of Sociolinguistics 4(3), 323-347.

Campbell-Kibler, Kathryn, Eckert, Penelope, Mendoza-Denton, Norma, \& Moore, Emma (2006). The elements of style. Poster, NWAV35, Ohio State University.

Copland, Fiona, \& Creese, Angela (2015). Linguistic ethnography: Collecting, analysing and presenting data. London: Sage Publications Limited.

Cormier, Kearsy, Smith, Sandra, \& Zwets, Martine (2013). Framing constructed action in British Sign Language narratives. Journal of Pragmatics 55, 119-139.

Coupland, Nikolas (2016). Introduction. In Nikolas Coupland (Ed.) Sociolinguistics: Theoretical debates (pp. 1-34). Cambridge: Cambridge University Press.

Drager, Katie (2013). Experimental methods in sociolinguistics: Matched guise and identification tasks. In Janet Holmes \& Kirk Hazen (Eds.), Research methods in sociolinguistics: A practical guide (pp. 58-73). Oxford: Wiley-Blackwell.

Eckert, Penelope (2000). Linguistic variation as social practice: The linguistic construction of identity in Belten High. Oxford: Wiley-Blackwell.

Eckert, Penelope (2008). Variation and the indexical field. Journal of Sociolinguistics, 12(4), 453-476.

Eckert, Penelope (2012). Three waves of variation study: The emergence of meaning in the study of sociolinguistic variation. Annual Review of Anthropology, 41, 87-100.

Eckert, Penelope (2019). Stylistic practice. Retrieved 15 June, 2019, from https://web.stanford.edu/ Eckert/csofp.html 
Eckert, Penelope, \& Rickford, John R. (Eds.) (2001). Style and sociolinguistic variation. Cambridge: Cambridge University Press.

Edwards, John (2011). Challenges in the social life of language. Basingstoke: Palgrave Macmillan.

Egbert, Maria M. (1997). Schisming: The collaborative transformation from a single conversation to multiple conversations. Research on Language and Social Interaction 30(1), $1-51$.

Eichmann, Hanna (2008). “Hands off our language!” Deaf Sign Language Teachers' perspectives on Sign Language standardisation. Doctoral dissertation, UCLAN.

Errington, J. Joseph (1985). Language and social change in Java: Linguistic reflexes of modernization in a traditional royal polity. Athens: Ohio University Press.

Errington, J. Joseph (1998). Shifting languages: Interaction and identity in Javanese Indonesian. Cambridge: Cambridge University Press.

Farrell, Emily J. (2008). Negotiating identity: Discourses of migration and belonging. Doctoral dissertation, Macquarie University, Australia.

Ferrara, Lindsay, \& Johnston, Trevor (2014). Elaborating who's what: A study of constructed action and clause structure in Auslan (Australian Sign Language). Australian Journal of Linguistics, 34(2), 193-215.

Fontana, Sabina (2008). Mouth actions as gesture in sign language. Gesture, 8(1), 104-123.

Gardner-Chloros, Penelope (2009). Code-switching. Cambridge: Cambridge University Press.

Goebel, Zane (2007). Enregisterment and appropriation in Javanese-Indonesian bilingual talk. Language in Society, 36(4), 511-531.

Grosjean, François (1982). Life with two languages: An introduction to bilingualism. Cambridge, MA: Harvard University Press.

Gumperz, John J. (1982). Discourse strategies. Cambridge: Cambridge University Press.

Hamid, M. Obaidul, \& Jahan, Iffat (2015). Language, identity and social divides: Medium of instruction debates in Bangladeshi print media. Comparative Education Review, 59(1), 75 101.

Hodge, Gabrielle, \& Ferrara, Lindsay (2013). Showing the story: Enactment as performance in Auslan narratives. In Lauren Gawne \& Jill Vaughan (Eds.), Selected Papers from the 44th Conference of the Australian Linguistic Society (pp. 372-397). Melbourne: University of Melbourne.

Hohenberger, Annette, \& Happ, Daniela (2001). The linguistic primacy of signs. In Penny Boyes-Braem \& Rachel Sutton-Spence (Eds.), The hands are the head of the mouth: The mouth as articulator in sign languages (pp. 153-190). Hamburg: Signum.

Hou, Lynn Y-S. (2016). "Making hands": Family sign languages in the San Juan Quiahije community. Doctoral dissertation, University of Texas, Austin.

Hou, Lynn Y-S., \& Kusters, Annelies (2019). Sign languages. In Karin Tusting (Ed.), The Routledge handbook of linguistic ethnography (pp. 340-355). Abingdon: Routledge.

Isma, Silva T.P. (2012). Signing varieties in Jakarta and Yogyakarta: Dialects or separate languages? Master's thesis, CUHK, Hong Kong.

Isma, Silva T.P., Bharoto, Adhi Kusumo, \& Novitasari, Opy (2018). When local meets formal: Influence of deaf education on color signs variation in Indonesian Sign Language. Second Workshop on Language, Literature and Society for Education, Solo, Central Java.

DOI:10.4108/eai.21-12-2018.2282747 
Jaworski, Adam, \& Coupland, Nikolas (2005). Othering in gossip: 'you go out you have a laugh and you can pull yeah okay but like...' Language in Society 34(5), 667-694.

Johnson, Daniel Ezra (2009). Getting off the GoldVarb Standard: Introducing Rbrul for mixedeffects variable rule analysis. Language and Linguistics Compass 3(1), 359-383.

Johnston, Trevor (1996). Function and medium in the forms of linguistic expression found in a sign language. In William H. Edmondson \& Ronnie B. Wilbur (Eds.), International review of sign linguistics, volume 1, (pp. 57-94). Mahwah, NJ: Lawrence Erlbaum.

Kusters, Annelies (2017). Gesture-based customer interactions: Deaf and hearing Mumbaikars' multimodal and metrolingual practices. International Journal of Multilingualism, 14(3), 283302.

Kusters, Annelies \& Friedner, Michele (2015). Introduction: Deaf-same and difference in international deaf spaces and encounters. In Michele Friedner \& Annelies Kusters (Eds.), It's a small world: International deaf spaces and encounters, (pp. ix-xxix). Washington, DC: Gallaudet University Press.

Labov, William (1994). Principles of linguistic change: Internal factors, volume 1. Oxford: Wiley-Blackwell.

Labov, William (2001). Principles of linguistic change: External factors, volume 2. Oxford: Wiley-Blackwell.

Ladd, Paddy (2003). Understanding deaf culture: In search of deafhood. Clevedon: Multilingual Matters.

Lane, Harlan (2005). Ethnicity, ethics, and the Deaf-World. Journal of Deaf Studies and Deaf Education 10(3), 291-310.

Lewin, Donna, \& Schembri, Adam (2011). Mouth gestures in British Sign Language: A case study of tongue protrusion in BSL narratives. Sign Language and Linguistics, 14(1), 94-114.

Llamas, Carmen (2006). Shifting identities and orientations in a border town. In Tope Omoniyi \& Goodith White (Eds.), The sociolinguistics of identity (pp. 92-112). London: Continuum.

Lucas, Ceil (2013). Methodological issues in studying sign language variation. In Laurence Meurant, Aurélie Sinte, Mieke Van Herreweghe, \& Myriam Vermeerbergen (Eds.), Sign language research, uses and practices: Crossing views on theoretical and applied sign language linguistics (pp. 258-308). Berlin: de Gruyter.

Lucas, Ceil, Bayley, Robert, \& Valli, Clayton (2001). Sociolinguistic variation in American Sign Language. Washington, DC: Gallaudet University Press.

Lucas, Ceil, \& Bayley, Robert (2016). Quantitative sociolinguistics and sign languages: Implications for sociolinguistic theory. In Nikolas Coupland (Ed.), Sociolinguistics: Theoretical debates (pp. 349-367). Cambridge: Cambridge University Press.

Lutzenberger, Hannah (2017). Negation in Kata Kolok: Grammaticalization throughout three generations of signers. Master's thesis, University of Amsterdam.

McCaskill, Carolyn, Lucas, Ceil, Bayley, Robert, \& Hill, Joseph (2011). The hidden treasure of Black ASL: Its history and structure. Washington, DC: Gallaudet University Press.

McIlroy, Guy, \& Storbeck, Claudine (2011). Development of deaf identity: An ethnographic study. The Journal of Deaf Studies and Deaf Education 16(4), 494-511.

McKee, Rachel (2019). Motivation and innovation in indexing Māori identity in New Zealand Sign Language. Presentation at the Symposium on Sociolinguistic Variation in Signed and Spoken Languages of the Asia-Pacific Region, University of Central Lancashire, 12-13 July 2019. 
McMahon, April M.S. (1994). Understanding language change. Cambridge: Cambridge University Press.

Metzger, Melanie (1995). Constructed dialogue and constructed action in American Sign Language. In Ceil Lucas (Ed.), Sociolinguistics in deaf communities (pp 255-271). Washington, DC: Gallaudet University Press.

Mohammad, Abeer, \& Vásquez, Camilla (2015). 'Rachel's not here': Constructed dialogue in gossip. Journal of Sociolinguistics 19(3), 351-371.

Myers-Scotton, Carol (1993). Social motivations for codeswitching: Evidence from Africa. Oxford: Clarendon Press.

Ochs, Elinor (2004). Narrative lessons. In Alessandro Duranti (Ed.), A companion to linguistic anthropology (pp. 269-289). Oxford: Wiley-Blackwell.

Ochs, Elinor, \& Capps, Lisa (2001). Living narrative. Cambridge, MA: Harvard University Press.

Padden, Carol A., \& Humphries, Tom (2006). Inside deaf culture. Cambridge, MA: Harvard University Press.

Palfreyman, Nick (2013). Form, function and the grammaticalisation of completive markers in the sign language varieties of Solo and Makassar.' NUSA: Linguistic studies of languages in and around Indonesia. Research Institute for Languages and Cultures of Asia and Africa (ILCAA), Tokyo.

Palfreyman, Nick (2015). Sign language varieties of Indonesia: A linguistic and sociolinguistic investigation. Doctoral dissertation, University of Central Lancashire.

Palfreyman, Nick (2016). Colour terms in Indonesian sign language varieties: A preliminary study. In Ulrike Zeshan \& Keiko Sagara (Eds.), Semantic fields in sign languages: Colour, kinship and quantification (pp. 269-300). Berlin: De Gruyter and Lancaster: Ishara Press.

Palfreyman, Nick (2019). Variation in Indonesian Sign Language: A typological and Sociolinguistic analysis. Berlin: De Gruyter and Lancaster: Ishara Press.

Palfreyman, Nick (in press). Managing sign language data from fieldwork. In Andrea BerezKroeker, Bradley McDonnell, Eve Koller, \& Lauren Collister (Eds.) The open handbook of linguistic data management. Cambridge, MA: MIT Press Open.

Robson, Stuart (2004). Welcome to Indonesian: A beginner's survey of the language. North Clarendon: VT: Tuttle Publications.

Schembri, Adam, \& Johnston, Trevor (2013). Sociolinguistic variation and change in sign languages. In Robert Bayley, Richard Cameron, \& Ceil Lucas (Eds.), The Oxford handbook of sociolinguistics (pp. 503-524). Oxford: Oxford University Press.

Schembri, Adam, McKee, David, McKee, Rachel, Pivac, Sara, Johnston, Trevor, \& Goswell, Della (2009). Phonological variation and change in Australian and New Zealand Sign Languages: The location variable. Language Variation and Change 21(2), 193-231.

Schilling-Estes, Natalie (2004). Constructing ethnicity in interaction. Journal of Sociolinguistics 8(2), 163-195.

Silverstein, Michael (2003). Indexical order and the dialectics of sociolinguistic life. Language and Communication, 23, 193-229.

Sloetjes, Han (2014). ELAN: Multimedia annotation application. In Jacques Durand, Ulrike Gut, and Gjert Kristoffersen (Eds.), The Oxford handbook of corpus phonology (pp. 305320). Oxford: Oxford University Press.

Sneddon, James N. (2003). The Indonesian language: Its history and role in modern society. Sydney: UNSW Press. 
Tagliamonte, Sali A. (2012). Variationist sociolinguistics: Change, observation, interpretation. Oxford: Wiley-Blackwell.

Tannen, Deborah (1989). Talking voices: Repetition, dialogue and imagery in conversational discourse. Cambridge: Cambridge University Press.

Taub, Sarah F. (2001). Language from the body: Iconicity and metaphor in American Sign Language. Cambridge: Cambridge University Press.

Vander Klok, Jozina (2012). Tense, aspect and modal markers in Paciran Javanese. Doctoral dissertation, York University, Montréal.

Van Cleve, John Vickrey, \& Crouch, Barry A. (1997). A place of their own: Creating the deaf community in America. Washington, DC: Gallaudet University Press.

Wijaya, Laura Lesmana (2017). Role shifting in Jakarta Sign Language: Subject-constructed actions, reference sequence and reference function. Bachelor's thesis, CUHK.

Wortham, Stanton (2006). Learning identity: The joint emergence of social identification and academic learning. Cambridge: Cambridge University Press.

Zeshan, Ulrike (2001). Mouthing in Indopakistani Sign Language (IPSL): Regularities and variations. In Penny Boyes Braem \& Rachel Sutton-Spence (Eds.), The hands are the head of the mouth (pp. 247-271). Hamburg: Signum.

Zeshan, Ulrike, \& Palfreyman, Nick (in press). Comparability of signed and spoken languages: Absolute and relative modality effects in cross-modal typology. In Nicholas Evans (Ed.) Comparability [Special issue]. Linguistic Typology.

Zhang, Qing (2008). Rhotacization and the 'Beijing smooth operator': The social meaning of a linguistic variable. Journal of Sociolinguistics 12(2), 201-222.

\begin{abstract}
Indonesian)
Dibandingkan penelitian sosiolinguistik pada bahasa lisan, kurang ada riset terhadap bagaimana pengguna bahasa isyarat memakai variasi sebagai sumber untuk mencipta makna sosial. Studi ini berfokus pada praktik sosial yang sangat tidak diperhatikan, yaitu penggunaan bahasa isyarat di Indonesia, dan menanyakan di mana bisa kita temukan variabel yang bermakna secara sosial. Menggunakan data spontan dari korpus BISINDO (Bahasa Isyarat Indonesia), makalah ini terapkan campuran metodologis dari variasi Labovian dan analisis 'third wave' bersamaan dengan pendekatan diskursif, untuk mempertimbangkan apakah dan sejauh mana empat fitur linguistik variabel digunakan untuk mengekspresikan identitas sosial. Fitur tersebut muncul pada tingkat organisasi linguistik yang berbeda, dari fonologis ke leksikal dan morfosintaktis, dan menunjuk pada identitas regional dan etnis, serta status pendengaran. Dalam menerapkan praktik third wave pada bahasa isyarat, menjadi jelas bahwa Constructed Action dan mouthing merupakan strategi yang sangat efektif untuk mencipta makna sosial.
\end{abstract}

\title{
Address for correspondence
}

Dr. Nick Palfreyman

International Institute for Sign Languages and Deaf Studies (iSLanDS Institute)

University of Central Lancashire

Preston PR1 2HE United Kingdom

nickpalfreyman@cantab.net 